\title{
‘TEACH US THE SECRET RUNES’. THE LORD'S PRAYER IN HELIAND
}

\author{
FRANK G. BOSMAN*
}

Tilburg University

\begin{abstract}
The ninth century Heliand is a poetic retelling of the New Testament in Old Saxon, written by an anonymous monk for the purpose of confirming the conversion his fellow Saxons to the new faith. This conversion had been forced upon them by the Frankish invaders. The author adepts the story of Jesus Christ to fit within the feudal Saxon society and precursory Nordic mythology. This contribution focuses on the Saxon rendering of the Lord's Prayer as it is situated in the context of the Sermon on the Mount. Several key differences between the Saxon version and its biblical original are pointed out. These mirror and illustrate the attempt of the anonymous author to inculturate Jesus' message. Finally, it is shown how, by some subtle phrases in the text of the Heliand, the poet of the Heliand is including his Saxon audience to fit themselves spiritually into the biblical story. Through the Heliand, Jesus seems to speak directly to its readers, thus stimulating a transformation of the reader-or hearer-himself.
\end{abstract}

KEY WORDS: Heliand, inculturation, cultural theology, Old Saxon (language), the Lord's Prayer.

Fadar ûsa / firiho barno, thu bist an them hôhon / himila rîkea, geuuîhid sî thîn namo / uuordo gehuuilico (lines 1600-1602). ${ }^{1}$ This is how 'Our Father' begins in the Old Saxon gospel harmony known as the Heliand: 'Father of us, the sons of men / You are in the high heavenly kingdom / Blessed be Your name in every word', in Ronald Murphy's English translation. ${ }^{2}$ The anonymous author of the Heliand lived in the first half of the ninth century. His work is addressed to his fellow Saxons, who had recently been forcibly converted to Christianity at the hands of their Frankish overlords. The poet of the Heliand does not force his audience to make the heart-rending choice between the 'old' and the 'new' way, but weaves the Christian narrative about Jesus of Nazareth into the wider framework of Nordic mythology.

FRANK G. BOSMAN (PhD 2014, Tilburg University) is cultural theologian and scientific researcher at the Cobbenhagen Center within Tilburg University's School of Humanities. Email: f.g.bosman@tilburguniversity.edu.

1 The Old Saxon text of the Heliand is derived from Taeger's edition (1984).

2 The English translation of the Heliand used in this article is derived from Murphy (1992). Sometimes an alternative English translation has been used that is phonetically closer to the original Saxon version; this is marked by [square parantheses]. 
This contribution will regard the Fadar ûsa as a synecdoche for the entire poetic masterpiece that is the Heliand. In addition to offering a critical translation, it will place the Fadar ûsa in its own literary context. It will focus primarily on what happens in this poetic Saxon version of 'Our Father'. What roles can be identified in this prayer? Who is the addressee? And especially: to whom does this text appeal on an emotional level? The text-immanent reader, whether this be the historical (Saxon) reader or the contemporary postmodern reader, is present in, and senses the appeal of, the text of the Fadar ûsa. As Philip Zaleski has strikingly put it: 'No prayer is more familiar, yet a mere twist of poetic diction makes it strange again, and in this strangeness a magical potency stands revealed' (Zaleski 2005: 54)

\section{The Heliand: a Saxon Gospel}

Heliand is Old Saxon for saviour-and is derived from helian, which means 'to heal' or 'to restore to health'-a term frequently used in Northern European Christian tradition to describe the figure of Jesus Christ. ${ }^{3}$ The term $\mathrm{He}$ liand does not actually appear in the text itself, but it received this name from J. A. Schmeller, who published the first printed edition in 1830. The Heliand was most likely written sometime between 825 and 850 . Because the poet probably used Hrabanus Maurus' (780-856) commentary on the Gospel of Matthew, the Heliand cannot have been written before 821 . The Latin preface of the text bears the heading Ludouicus pissimus August ('Louis, our most pious emperor'), because it was probably Louis who commissioned the author to write it. The Louis in question could be Louis the Pious, who ruled the Frankish empire between 814 and 840 , but it could also refer to his son Louis the German, who formally assumed the government of all of East Francia in 843, but regarded himself as king of this realm from 833 onwards. In the latter case, the Heliand cannot have been written before 833 . This leaves us with a margin of twenty-five years between 825 and 850 .

We know next to nothing about the author of the Heliand. According to the Latin preface he was a man of Saxon heritage who was counted among the respected poets by his countrymen. This last aspect can easily be confirmed by reading the Heliand itself: form and vocabulary show a writer well versed and skilled in traditional poetry based on oral tradition. Poets declaimed their texts from memory and/or improvised parts on the spot. The Heliand is unique because it gives us insight into a culture primarily bound together by oral lore. The author obviously enjoyed theological schooling, because in addition to the four gospels he was also acquainted with other written theological sources. 
It is no surprise therefore that scholars have looked to a monastery in, or very close to Saxon territory as the place where the Heliand was written. There has been much speculation about the precise location, but the monasteries of Werden and Fulda are often mentioned. Werden was one of the most important monasteries in Saxon territory. Fulda is a good candidate, on the other hand, because under the leadership of Hrabanus Maurus it had developed into the most important centre of theology on Saxon territory. Fulda must have had all the books that the author used.

The language of the Heliand is Old Saxon, a language spoken in the early Middle Ages between the Ijssel and the Elbe: the eastern part of the Netherlands and the northern part of Germany. Apart from the Heliand and a number of fragments of Genesis that are strongly related to this text, very few texts in this language have been preserved. The primary reason for this is that the ancient Saxons did not have a tradition of written literature. In addition, Christendom used the universal language of Latin. The Heliand with its six thousand verses is therefore the most important source for this language, as well as for the culture of ancient Saxony. The great advantage of Old Saxon is that it is actually not difficult to understand for modern Dutchand German-speakers, especially if it is declaimed out loud. In this article, I will frequently use the Old Saxon text, because it is surprisingly close emotionally to our own language and time.

The style of the Heliand is that of Old Germanic alliteration verse. Each verse line (long verse) consists of two halves (half verses) separated by a respiratory pause. Each half verse has two stressed syllables.

The poet not only knew the Latin translation of the four gospels, and Hrabanus Maurus' commentary on the Gospel of Matthew, but very probably also Tatian's Diatesseron. The Syrian Tatian compiled the first 'gospel harmony' in $170 \mathrm{AD}$, probably in Syriac or Greek; unfortunately, this work has been preserved only in translated versions. The Latin translation of the Diatesseron was clearly known to the author of the Heliand. This can be inferred not only from certain phrases that appear to be derived from Tatian rather than the gospels themselves, but also from the fact that the author of the $\mathrm{He}$ liand chose to construct a harmony in the first place. The poet combined information from the four canonical gospels, Hrabanus Maurus' commentary on the Gospel of Matthew and Tatian's harmony, so as to present a single, continuous and integral narrative about Jesus.

The Jesus of this unique text is not the Jewish prophet of the New Testament, but a rough warrior chief, who moves from fortress to fortress together with his band of vassals. This Saxon Jesus is a 'soothsayer' who teaches his followers secret runes and works spectacular miracles. The Heliand is a great example of inculturation: the fusion of old (Nordic) and new (Christian) religion. In order to do this, the anonymous poet deploys a wide literary and 
intellectual repertoire to give the recently converted Saxons a Jesus that they can understand and in whom they can begin to believe. The result is a brilliant and enduringly appealing mixture of the Mediterranean biblical story and Nordic paganism, which does not force the reader to abandon his old faith, but invites him to view it from a different perspective.

\section{Inculturation}

In achieving this, the Heliand is an excellent example of what in theological circles is called 'inculturation'. This concept originated in the Roman Catholic theological tradition, especially in the Jesuit school. The Societas Jesu (or 'Society of Jesus') is a special order within the Roman Catholic Church, founded in 1534 in Paris by Ignatius of Loyola and a group of fellow students and friends. The Jesuits subsequently acquired the reputation of being the Vatican's intellectual 'shock troops'. Both in the Old World (Europe) and in the New (the European colonies), they provided education for the local elite, which gave them exceptionally large influence worldwide. Not infrequently this led to conflicts between the Jesuits and various secular and ecclesiastical rulers. Thus pressure from the kings of France, Spain, and Portugal led to the suppression of the order by Pope Clement XIV in 1773 (Dominus ac Redemptor). It was only re-established in 1814, but in fact its worldwide network had ensured that it had never totally disappeared. In Western collective consciousness, the Jesuits are probably best known by their courageous (and historically accurate) role in the 1986 film The Mission. This film shows a small group of Jesuits who remain faithful to 'their' indigenous faithful, and who have to pay for this with their lives as a result of church political intrigue between Spain, Portugal, and the Vatican. Jesuits honour their missionary tradition of assimilation into their host culture. In a certain sense they embody the ideal of inculturation.

The Jesuit Pedro Arrupe has given a clear definition of 'inculturation', a definition that is entirely consistent with Ignatian spirituality:

The incarnation of Christian life and of the Christian message in a particular cultural context, in such a way that this experience not only finds expression through elements proper to the culture in question (this alone would be no more than a superficial adaptation) but becomes a principle that animates, directs and unifies the culture, transforming it and making it so as to bring about a 'new creation'. (Quoted in Shorter 2006: 11)

Arrupe indicates that inculturation does not involve superficial adaptation of the Christian narrative to a particular culture, but that it means anchoring the Christian message in the deepest level of a culture's collective soul. It is not about suppressing 'pagan' culture and religion, but about establishing a synthesis between paganism and Christianity, where the 'pagan' is not asked 
to abandon his old ideas, but is challenged to view them in a different light. The ultimate theological goal of this form of inculturation is to realise that the one truth (God) reveals himself in innumerable different ways in cultures and religions across the world. Pope Francis, himself a Jesuit, formulated this as follows in his 2013 encyclical Evangelii Gaudium:

This is because each people is the creator of their own culture and the protagonist of their own history. Culture is a dynamic reality which a people constantly recreates; each generation passes on a whole series of ways of approaching different existential situations to the next generation, which must in turn reformulate it as it confronts its own challenges... This is an ongoing and developing process, of which the Holy Spirit is the principal agent.

The transition which 'Our Father' undergoes in the Heliand is part of precisely this tradition of inculturation, as will become clear in this article. This way as well, the Fadar ûsa is a beautiful synecdoche for the entire Heliand.

\section{Fadar îsa: the Saxon 'Our Father'}

We turn now to the Fadar ûsa, which can be found in verses 1600 to 1612 in the Heliand (at the beginning of the nineteenth 'song' or chapter). The literary context of the prayer will be discussed further on in this section, which begins with a presentation of the text and a critical translation of the most important concepts. ${ }^{4}$

\section{Text and Translation}

The text according to the Burkhard Taeger edition is as follows:

1600 Fadar ûsa / firiho barno,

1601 thu bist an them hôhon / himila rîkea,

1602 geuuîhid sî thîn namo / uuordo gehuuilico.

1603 Cuma thin / craftag riki.

1604 Uuerða thîn uuilleo / obar thesa uuerold alla,

1605 sô sama an erðo, / sô thar uppa ist

1606 an them hôhon / himilo rîkea.

1607 Gef ûs dago gehuuilikes râd, / drohtin the gôdo,

1608 thîna hêlaga helpa, / endi alât ûs, heநenes uuard,

1609 managoro mên sculdio, / al sô uue ồrum mannum dôan.

1610 Ne lât ûs farlêdean / lêða uuihti

1611 sô forð an iro uuilleon, / sô uui uuirðige sind,

1612 ac help ûs uuiðar allun / ubilon dâdiun. 
Ronald Murphy has translated this as follows:

1600 Father of us, the sons of men,

1601 You are in the high heavenly kingdom,

1602 Blessed be Your name in every word.

1603 May Your mighty kingdom come.

1604 May Your will be done over all this world,

1605 just the same on earth as it is up there

1606 in the high heavenly kingdom.

1607 Give us support each day, good chieftain,

1608 your holy help, and pardon us, Protector of Heaven,

1609 our many crimes, just as we do to other human beings.

1610 Do not let evil little creatures lead us off

1611 to do their will, as we deserve,

1612 but help us against all evil deeds.

A number of textual elements merit further examination. ${ }^{5}$ The phrase fadar ûsa ('our Father') is supplemented by firiho barno ('[of] the children of men'): 'Father of us, the children of men'. This stretches the scope of us to its furthest limits, by including every human being. To geuuîhid sî thîn namo ('blessed [hallowed, sanctified] be your name') an extra phrase is added: uuordo gehuuilico ('[in] all words'). Murphy suggests that this addition demands a more active attitude on the part of the person who prays: all the words that a believer speaks must be directed to praising and sanctifying God's name (Murphy 1992: 55). The poet has extended the traditional petition 'Thy will be done, on earth, as it is in heaven' to three lines: obar thesa uuerold alla ('on this entire world'), sô sama an erðo, / sô thar uppa ist ('so the same on earth / so [the same] there above') and an them hôhon / himilo rikea ('in the highest / heavenly kingdom [reign]').

The adaptation that stands out most can be found in the verses 1607-1608. Instead of the well-known phrase 'Give us this day our daily bread', the poet has Jesus teach his disciples to pray for dago gehuuilikes râd ('every day support [counsel]') and thîna hêlaga helpa ('your holy help'). Murphy has pointed to the Heliand's feudal context to explain the replacement of 'bread' by 'help'. It would have seemed odd to wealthy Saxon aristocrats to ask God for bread, but good counsel is something that never goes amiss (Murphy 1992: 55). Van Vredendaal, on the other hand, has argued that this adaptation in the Heliand is due to Hrabanus Maurus' commentary on Matthew, which presents daily bread as a synecdoche for all life's necessities (Van Vredendaal 2006: 105).

Two further divine titula are mentioned in addition to the first verse's $f a$ dar ûsa: drohtin the gôdo ('good chieftain') and heђenes uuard ('protector of 
heaven [heavenly ward]'). It is an interesting question to whom these three titula refer: to God the Father, the poem's primary addressee, or to Jesus, the primary person who pronounces the prayer? The titles fadar ('father') and uuard ('ward') can both refer without the slightest difficulty to the heavenly Father, but the term drohtin (a kind of army commander) is reserved exclusively to Jesus in the Heliand.

The poet of the Heliand has rendered the complicated Greek kai mé eisenegkēs hèmas eis peirasmon (traditionally translated as 'and forgive us our trespasses, as we forgive those who trespass against us, and lead us not into temptation, but deliver us from evil') in typically distinct fashion: ne lât $\hat{u} s$ farlêdean / lểa uuihti ('do not let evil little creatures let us off [tempt us]') (Murphy 1992: 55). Here too he adds another phrase (which is not easy to translate), sô forð an iro unilleon, / sô uui uuirðige sind, which more or less means 'though we are worthy to abide by the will (of the demons)'. At the same time, however, the poet also makes it clear that evil cannot simply be ascribed to an external cause (as in 'the devil made me do it!'). He has Jesus conclude the Fadar ûsa with ac help ûs uuiðar allun / ubilon dâdiun. This means 'but help us against all evil deeds' and refers to the evil deeds that others do to us, as well as to the crimes that we-in our turn—commit against others (Murphy 1992: $56)$.

\section{Literary Context}

Just as in Matthew, the Fadar ûsa in the Heliand is situated in the wider context of the Sermon on the Mount (Matthew 5-7; see also Luke 6:17-49). The Sermon on the Mount in the Heliand begins at the sixteenth song (1279) and ends at the twenty-third (1993). The 714 verses of this version of the Sermon on the Mount form approximately one-eighth of the total number of verses (5983). The sixteenth song begins as follows:

1279 Thô umbi thana neriendon Krist / nâhor gengun

1280 sulike gesîðos, / sô he im selbo gecôs,

Then the warrior-companions whom He chose from among the people gathered closer around Christ, the Ruler and Rescuer.

Who are these people who gather closely around Jesus? At first sight they seem to be the gesiðos ('warrior-companions'), the word that the Heliand always uses to describe the twelve disciples. The poem even adds 'whom he (Jesus) chose'. But the end of the fifteenth song, which directly precedes the above quotation, offers scope for a wider interpretation.

1274 managoro mundboro, / the allumu mancunnie

1275 uuið hellie gethuuing / helpan uuelde, 
1276 formon uuið them ferne, / sô huuem sô frummien uuili

1277 sô lioblîka lêra, / sô he them liudiun thar

1278 thurh is giuuit mikil / uuîsean hogda.

The protector of many people, who wanted to help all of mankind against the oppressive forces of Hell, the infernal power - to help anyone who wanted to follow the lovely teachings which He intended to explain to the people there with His great knowledge and understanding.

This way, the poet extends the group of those who listen to the Sermon on the Mount to everyone, 'all of mankind', anyone who 'wanted to follow' Jesus' 'lovely teachings' (lioblikka lêra). The following eight songs that make up the Sermon on the Mount in the Heliand then give the content of these 'lovely teachings'. The Fadar ûsa is located exactly in the middle of these eight songs. A similar extension of the group of people intended occurs at the end of the twenty-third song, which concludes the Sermon on the Mount in the Heliand. The poet ends on the following words:

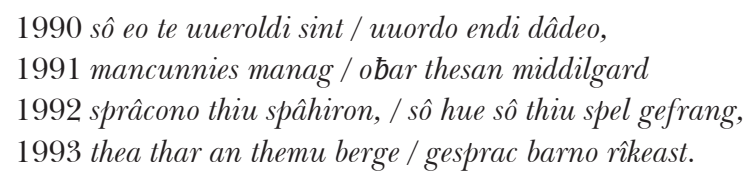

Whoever of the many members of the human race throughout this middle world is wiser in word and deed when he speaks, is one who heard the spell spoken on the mountain by the most Powerful of those born.

Again the poet speaks in an inclusive way: he speaks of 'many members of the human race [many men]' (mancunnies manag) who gain wisdom in 'word and deed' (uuordo endi dâdeo) when they hear Jesus' 'spell'.

The nineteenth song deals with a conversation between one of the disciples and Jesus which precedes the Fadar $\hat{u} s a$. The disciples ask Jesus: 'teach us how to pray' (that thu $\hat{u}$ s bedon lêres, verse 1590), just as John the Baptist taught his disciples (verse 1591), 'teach us the secret runes' (gerihti $\hat{u}$ s that gerûni, verse 1595). Jesus then answers:

1597 Than gi god uuillean, quað he,

1598 uueros mid iuuuon uuordun / uualdand grôtean,

1599 allaro cuningo craftigostan, / than queðad gi, sô ic iu lêriu

When you men want to speak to the ruling God, to address the most powerful of all kings, then say what I now teach you.

The 'what' (sô) in verse 1599 points forward to the entire Fadar $\hat{u} s a$. The 'you' (iu) in the same verse can-once again-be interpreted either in an inclusive

PERICHORESIS $14.2(2016)$ 
or an exclusive way. Either it refers to the disciples, one of whom has asked Jesus how they should pray, or it refers to the group mentioned before, that is anyone who wishes to listen to Jesus' words and act accordingly. The following section will address the consequences of this inclusive way of writing.

\section{Secret Runes: Initiation and the Fadar ûsa}

To discover the deeper meaning of the Fadar usa, especially in the context of 'initiation', we will first read the text diachronically and then synchronically.

\section{Diachronic Reading: Jesus as the Lord of Runes}

The Franks adopted the Christian faith around 500. They subsequently began to regard themselves increasingly as the heirs to the Western Roman Empire, and therefore also as the protectors of the 'Roman empire'. Frankish rulers consequently enthusiastically supported the ecclesiastical structure with its bishops. Frankish territorial expansion went hand in hand with Christianisation. In 772, the famous Frankish king Charlemagne began a thirty years' war against the defiant Saxons in the north. All historians agree that the Frankish conquest was particularly cruel. In 782, Charlemagne had thousands of prisoners of war put to death, while implementing strict religious laws and deporting rebellious Saxons to far-off Frankish territory. In 800 he had more or less completed his conquests, and then had himself crowned emperor of the imperium christianum by the pope. The poet of the Heliand, himself a Saxon monk, found himself facing considerable difficulties in his work. Convinced of the truth of the Christian faith, he wanted to make the gospel stories accessible to his countrymen, in a language that they would be able to understand. The Heliand is therefore both a harmony and inculturation in one, as the examples mentioned above have demonstrated. The Saxons, however, associated Christianity with their despised Frankish overlords. The poet therefore had to carry out a complicated theological and cultural balancing act, of which the Heliand, and as part of it, the Fadar ûsa, are the result.

One of the many ways in which the poet tried to narrow the gap between (Frankish) Christianity and his Saxon audience was to use the concepts of spel ('spell', verse 1992) and gerûni ('runes', verse 1959), which we have already encountered in the context of the Fadar ûsa. The poet summarises the entire Sermon on the Mount and the Fadar ûsa by using the concept of spel. Van Vredendaal has translated this as 'words', but its meaning is much richer. The original meaning is best represented by the English word spell, which means 'enchantment' or 'incantation'.

In verse 25, at the very start of the Heliand the author calls the four gospels (and indirectly his own work) godspell, a beautiful contraction of the words god and spell. Because the Saxon word god can mean both 'deity' and 'good', 
it contains an echo of the Greek word for gospel-eu-aggelikon-which also means 'good message'. The word gospel in modern English, the standard English translation of eu-aggelikon, still bears witness to this play on words.

The association with powerful spells is also evoked by using the word gerûni in verse 1595 (and elsewhere). The Fadar ûsa thus becomes a 'rune', a sacred word that gives direct access to the gods, and to the wisdom of Wodan, the 'god of the runes' in Nordic mythology. The poet does not mention Wodan, but by using the word gerûni he turns 'Our Father' into an incantation that can be used to ward off evil and invoke divine grace (Murdoch, Read 2004: 275; Murphy 1989: 90).

Synchronic Reading: Initiation into the Mystery of God

A synchronic reading of the Fadar ûsa reveals a powerful text imbued with strong spiritual appeal. The division of roles in, preceding and following the Fadar reveals a number of things. Read superficially, the Fadar ûsa appears to be Jesus' prayer to God the Father, spoken in front of the group of twelve disciples at the request of one of them. The disciple says: 'Teach us how to pray (...) teach us the secret runes'. Jesus answers him, and through him he answers the group of the Twelve, who have been listening since the beginning of the Sermon on the Mount. Let me quote the text once more:

1597 Than gi god uuillean, quað he,

1598 uueros mid iuuuon uuordun / uualdand grôtean,

1599 allaro cuningo craftigostan, / than queðad gi, sô ic iu lêriu

When you men want to speak to the ruling God, to address the most powerful of all kings, then say what I now teach you.

Nevertheless, this simple division of roles-the disciples (group), the disciple who makes the request, Jesus who pronounces a prayer and God as the one to whom the prayer is addressed-is disrupted, or rather: broken open, by the wider context of the Sermon of the Mount, of which the Fadar ûsa is the centrepiece. At the end of the fifteenth song, just before the Sermon on the Mount begins, the poet addresses the reader of the Heliand personally: He tells his audience that Jesus wants 'to help anyone who wanted to follow the lovely teachings which He intended to explain to the people there with His great knowledge and understanding'.

The poet refers to the Sermon on the Mount, which takes centre stage in the composition of the Heliand, and encourages his readers to listen to what Jesus has to tell them, because 'great knowledge' can be found there. The poet defines the audience he is addressing as widely as possible: 'all of mankind (...) anyone who wanted to follow the lovely teachings'. It is not for nothing that the opening phrase Fadar $\hat{u} s a$ is followed by the addition firiho barno,

PERICHORESIS 14.2 (2016) 
'of all children of men'. The God of Jesus is not just the father of a number of elect, but of everyone who lives in middle world.

This places the start of the sixteenth song, the beginning of the Sermon of the Mount, in an entirely new light:

1279 Thô umbi thana neriendon Krist / nâhor gengun

1280 sulike gesîðos, / sô he im selbo gecôs,

1281 uualdand undar them uuerode. / Stôdun uuîsa man,

1282 gumon umbi thana godes sunu / gerno suû̃ðo

Then the warrior-companions whom He chose from among the people gathered closer around Christ, the Ruler and Rescuer.

The 'warrior-companions' Jesus 'chose from among the people' are no longer just the twelve disciples, but anyone who 'wants to follow' the 'great knowledge' of the drohtin, i.e. anyone who hears, proclaims or privately reads the text of the Heliand. The composition of the text places the reader of the text in the company of the Twelve who listen to Jesus during his Sermon on the Mount. You are a disciple of Jesus because you listen to the Heliand, and listening to the Heliand is sitting at Jesus' feet as one of his disciples, to hear about the secrets of God's kingdom, with the Fadar ûsa as climax. The phrase 'the warrior-companions whom He chose' also indicates that the reader of the text of the Heliand, as such, has been personally called by Jesus to follow him and to listen to him.

The conclusion of the Sermon on the Mount in the Heliand (the end of the twenty-third song) does precisely the same. The poet speaks about "many members of the human race throughout this middle world (...) is wiser in word and deed', when they 'heard' the words of Jesus. This text speaks about the Sermon on the Mount in the present, not as a historical event that happened long ago in a strange and distant land. The poet is in fact speakingonce again-about the reader/hearer of the Heliand, who has just read or heard the entire Sermon on the Mount and the Fadar ûsa.

When Jesus then addresses gi or iu ('you', plural), just before saying the Fadar ûsa, the reader of the Heliand immediately knows he is being addressed himself. The 'us' in 'teach us how to pray' includes the reader. It is also the reader's question: if I am to pray, how do I do this? Jesus' answer, 'when you want to speak to the ruling God (...) say what I now teach you', is therefore also addressed to the reader. The author of the Heliand steers his audience in such a way until it is seated at Jesus' feet, listening to his words. The reader is initiated into the mystery of God's Son on earth by listening to his own words. At the moment that the text is spoken, 'we' as readers/hearers are sitting on the mount at Jesus' feet. The author does not present a report of a historical event, but actualises the event described as something taking place 
here and now, and that exercises 'power' over the present. The text happens now; it happens to the reader/hearer. The Fadar ûsa is not about an event, it is itself initiation, and the reading/hearing of the Heliand is itself the ritual of initiation, i.e. the act of listening to Jesus who at this very moment in and through the text is sharing his wisdom with anyone who cares to listen.

Another changing of dramatic roles occurs in the Fadar ûsa itself. At first sight, this appears to be a prayer that Jesus addresses to his heavenly Father, just as it is in the Greek original. But there is a strange caesura between verses 1606 and 1607. Up until 1606, the addressee is clearly God the Father: 'You are in the high heavenly kingdom / Blessed be Your name in every word / May Your mighty kingdom come. / May Your will be done over all this world, /just the same on earth as it is up there / in the high heavenly kingdom'. But after this comes the petition for 'support each day', followed by the titula of drohtin the gôdo ('good [divine] chieftain [warlord]'). As has been seen, the title of drohtin is used exclusively for Jesus in the Heliand.

In using this title, the author leaves open the possibility that the second part of the Fadar ûsa is not addressed to the heavenly Father, but to Jesus himself. The following titula, in the next verse, is ambivalent. The phrase heநenes uuard ('protector of the Heaven [heavenly ward]') can refer both to Jesus and to God the Father. It is possible, however, that the poet was intentionally ambivalent to strengthen the identification between God and Jesus. The things that are requested in prayer from verse 1607 onwards (daily counsel, forgiveness of sins, protection against evil/the evil one), are the kinds of things that Jesus actually delivers in the Heliand. Jesus gives daily counsel, through the Heliand, not only then, but also for and in the present. In several passages of the Heliand Jesus forgives sins. After all, Jesus' entire ministry, in life and death, is one great 'incantation' against the influence of darkness.

\section{Conclusions}

The author of the Heliand achieves two things with his poetic Old Saxon version of the prayer 'Our Father'. First he manages to inculturate the text and message of 'Our Father' into the context of his audience. Jesus is the drohtin, who teaches his disciples spells and geruni, and who is more powerful than Wodan. But the second achievement is even more forceful. Whether his readership consists of ninth-century Saxon aristocrats or twenty-first-century readers from Western Europe, the Sermon on the Mount and the Fadar ûsa which is part of it are rendered in such a way as to make the reader / hearer feel part of the magic circle formed by Jesus addressing his disciples. The reader / hearer of the Heliand personally becomes a hearer of Jesus' Sermon on the Mount. This identification is twofold. Not only is the reader / hearer placed among the disciples of Jesus, who are mentioned in the text, but the act of reading / hearing the Heliand is in itself a form of initiation into Jesus' 
secrets. As the disciples on the mount listen to Jesus (and the disciples stand for anyone who reads / hears the Heliand), so we listen to the Heliand.

By using this clever literary device, the author of the Heliand succeeds in narrowing the distance between the text and the reader to such a degree that it almost disappears. The poet addresses the reader, not just literally, but also intellectually and emotionally. Each 'we' and each 'you' in, preceding and following the Fadar ûsa directly refers to the reader of the text. We, as readers / hearers of the Heliand, are initiated into Jesus' runes, into his secret teaching. This is why the reader/hearer can also wholeheartedly accept the Fadar ûsa, firiho barno, 'Father of all the children of men, our Father'.

\section{Bibliography}

Taeger B (1984) Der Heliand. Frankfurt.

http://titus.uni-frankfurt.de/texte/etcs/germ/asachs/heliand/helialex.htm [accessed on 03-03-16].

Murphy R (1989) The Saxon Saviour. The Germanic Transformation of the Gospel in the Ninth-Century Heliand. Oxford: Oxford University Press.

Murphy R (1992) The Heliand, the Saxon Gospel. A translation and commentary. Oxford: Oxford University Press.

Murphy R (2013), Tree of Salvation: Yggdrasil and the Cross of the North. Oxford: Oxford University Press.

Zaleski P (2005) Prayer: A History. Boston, MA: Houghton Mifflin.

Pakis VA (2006) Perspectives on the Old Saxon Heliand. Introductory and Critical Essays, with an Edition of the Leipzig Fragment. Morgantown, WV: West Virginia University Press.

Robinson O (1992) Old English and its Closest Relatives: A Survey of the Earliest Germanic Languages. Stanford, CA: Stanford University Press.

Van Vredendaal J (2006) Heliand. Een Christusgedicht uit de vroege middeleeuwen. Amsterdam: SUN.

Murdoch B, Read M (2004) Early Germanic Literature and Culture. Rochester: Camden House.

Shorter A (2006) Towards a Theology of Inculturation. London: Geoffrey Chapman. 